\title{
Correction to: The aluminium-[18F]fuoride revolution: simple radiochemistry with a big impact for radiolabelled biomolecules
}

Stephen J. Archibald ${ }^{1,2,3}$ and Louis Allott ${ }^{1,2,3^{*}}$

The original article can be found online at https://doi. org/10.1186/s41181-02100141-0

\section{*Correspondence:}

louis.allott@hull.ac.uk

1 Positron Emission

Tomography Research

Centre, Faculty of Health

Sciences, University of Hull,

Cottingham Road, Kingston upon Hull HU6 7RX, UK

Full list of author information is available at the end of the article
Springer Open

\section{Correction to: EJNMMI Radiopharm. Chem. (2021) 6:30 https://doi.org/10.1186/s41181-021-00141-0}

Following publication of the original article (Archibald and Allott 2021), the authors identified an error in Table 2 and Fig. 3. The correct table and figure are given below.

The original article (Archibald and Allott 2021) has been corrected.

Table 2 Prominent examples of [18F]AlF radioconjugates discussed in this review

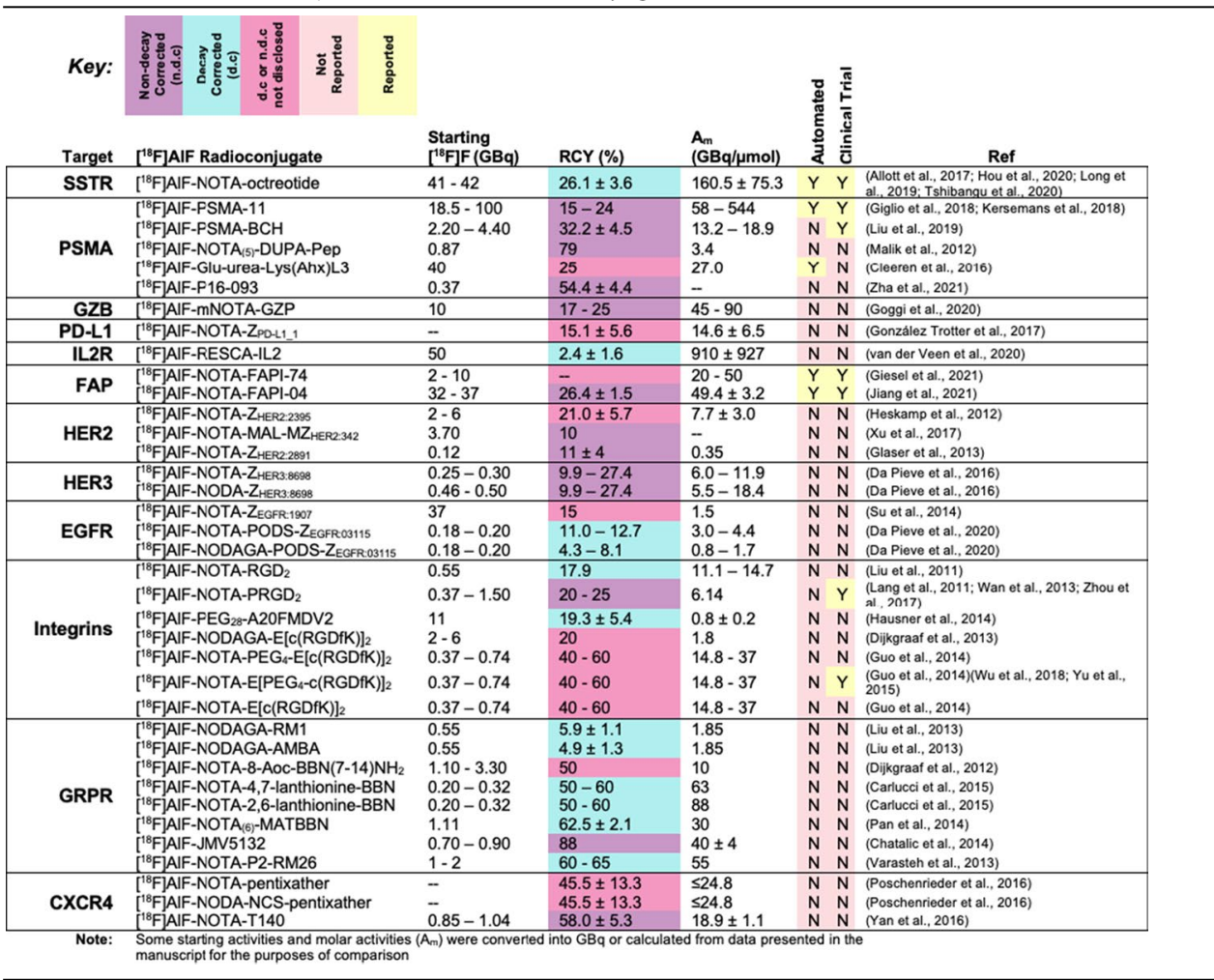

(O) The Author(s) 2021. Open Access This article is licensed under a Creative Commons Attribution 4.0 International License, which permits use, sharing, adaptation, distribution and reproduction in any medium or format, as long as you give appropriate credit to the original author(s) and the source, provide a link to the Creative Commons licence, and indicate if changes were made. The images or other third party material in this article are included in the article's Creative Commons licence, unless indicated otherwise in a credit line to the material. If material is not included in the article's Creative Commons licence and your intended use is not permitted by statutory regulation or exceeds the permitted use, you will need to obtain permission directly from the copyright holder. To view a copy of this licence, visit http:// creativecommons.org/licenses/by/4.0/. 


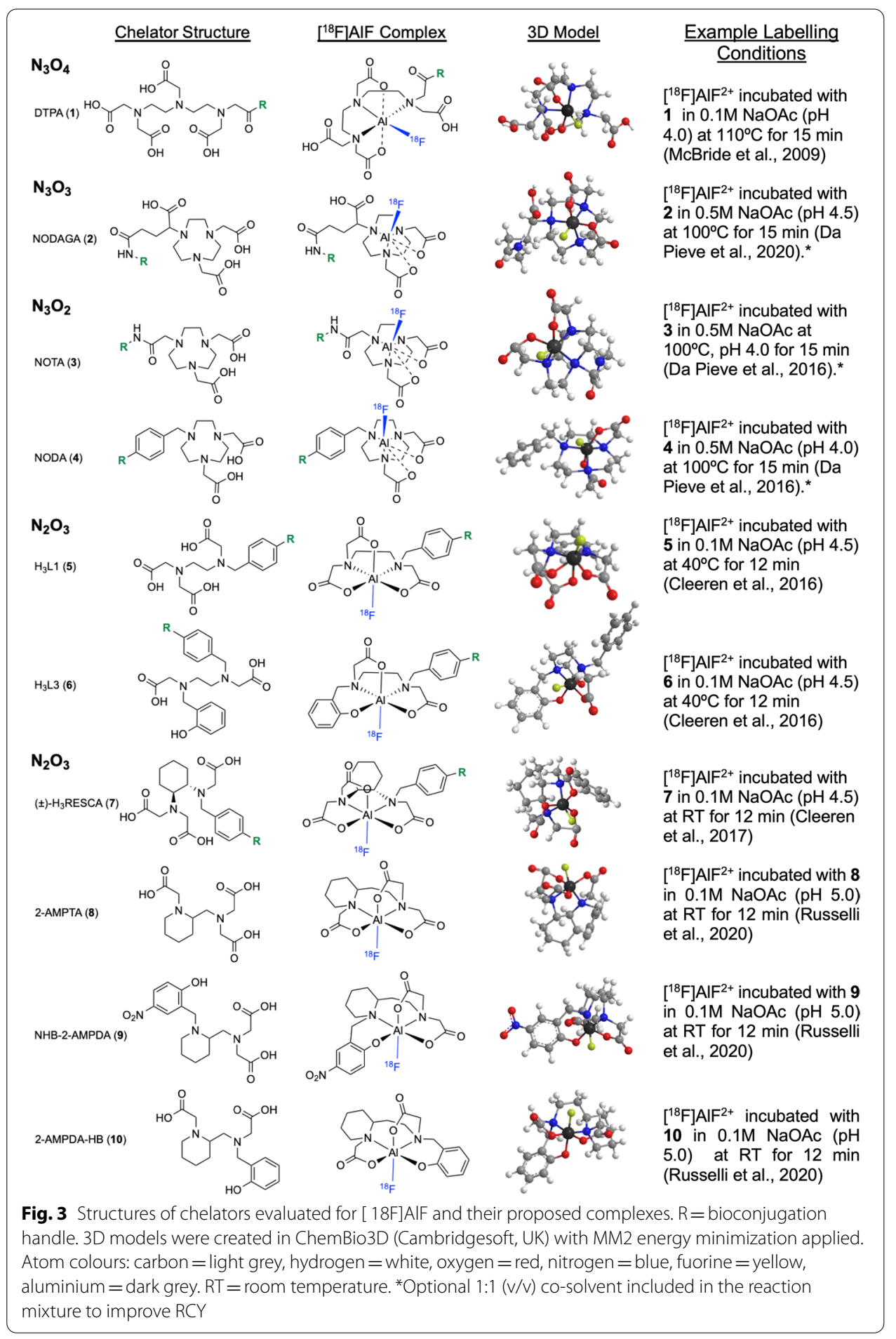

\section{Author details}

${ }^{1}$ Positron Emission Tomography Research Centre, Faculty of Health Sciences, University of Hull, Cottingham Road, Kingston upon Hull HU6 7RX, UK. ${ }^{2}$ Department of Biomedical Sciences, Faculty of Health Sciences, University of Hull, Cottingham Road, Kingston upon Hull HU6 7RX, UK. ${ }^{3}$ Hull University Teaching Hospitals NHS Trust, Castle Hill Hospital, Castle Road, Cottingham HU16 5JQ, UK. 


\section{Reference}

Archibald and Allott EJNMMI Radiopharm. Chem. (2021) 6:30 https://doi.org/10.1186/s41181-021-00141-0

\section{Publisher's Note}

Springer Nature remains neutral with regard to jurisdictional claims in published maps and institutional affiliations. 